\title{
FRIEDRICH SCHILLER'S ADUALISTIC CONCEPTION OF UNITY
}

\author{
By Manuel Dries \\ Girton College, Cambridge
}

This paper considers three general dilemmas that tend to undermine successful configurations of unity: the either/or dilemma, the synthesis dilemma and the relativism dilemma. It further argues that, in his aesthetic writings, Schiller's critique of Kantian dualisms leads him to an adualistic conception of unity that operates with a different, more inclusive approach to opposition and unification. In order to clarify Schiller's innovative and often misunderstood position, the paper draws on the disjunctive logic recently developed by Friedrich Kümmel.

\section{An den Dichter}

Laß die Sprache dir seyn, was der Körper den Liebenden; er nur Ists, der die Wesen trennt und der die Wesen vereint. ${ }^{1}$

$\mathrm{S}$ chiller's idea of unity has provoked debate among his critics over the past two centuries. I want to argue that his specific practice of dealing with oppositions still deserves our attention today. In various respects, what Schiller has to say in his theoretical writings makes an important contribution to what one might want to call a phenomenology of conflict, conflict resolution and a concomitant theory of unification, and this contribution has, to my knowledge, largely been misinterpreted. $^{2}$ This paper falls into four parts. In the first part, I will discuss what I see as the three dilemmas of unification, using the European Union as an example. In the second part, I present Schiller's critique of Kant's dualistic style of thought. The third part attempts to elucidate Schiller's innovative, adualistic conception of unity, with reference to the disjunctive logic developed by Friedrich Kümmel. And while I shall not pursue in detail here the (to my mind, important) insights to be found in Schiller's literary writings, I shall end with an interpretation of the relationship between Berta and Rudenz in Wilhelm Tell.

For many, the driving force behind the project of a unified Europe has been the ideal of a unity that would once and for all prevent the possibility of another war. In order to overcome the linguistic, historical, social and political differences between the nation states, a unified Europe is supposed to offer a platform of reconciliation and a new European identity for all participants. ${ }^{3}$ But establishing unity between

\footnotetext{
${ }^{1}$ Friedrich Schiller, 'Musenalmanach für das Jahr I797' (NA, I, 302). I would like to thank Walter Schmoll for the many discussions of the issues treated in this paper we had over the past five years. I have profited particularly from comments on earlier versions by Raymond Geuss, John Guthrie, Mark Henderson and Manolis Simos. To Barry Nisbet and Lesley Sharpe I am indebted for years of instruction and encouragement.

${ }^{2}$ See, for example, Hans-Georg Gadamer, Wahrheit und Methode, Tübingen, third edition, I972, p. 78, and Jürgen Habermas, Die Moderne - ein unvollendetes Projekt, Leipzig, I990, p. 46.

${ }^{3}$ An additional factor might also be that the former national identities were largely based on the principle that 'omnis determinatio est negatio': to be German meant not being, say, English, French, or Russian. A practice of identification by negation makes integration all the more difficult.
} 
entities that are undeniably different from one another proves problematic because of what I want to call the three dilemmas of unification: the either/or dilemma, the synthesis dilemma and the relativist dilemma.

When unity is established via an either/or decision, out of the various alternative models, one model (for example, the German federal model) becomes binding for all participants. A unity based on such an either/or decision is likely to generate discontent, the differences return, and conflict is likely to reappear.

When unity is established via a synthesis, the participating groups usually agree on a middle ground. Either this leads to a 'lowest common denominator' which is quickly perceived to be unsatisfactory, or, when the goal is an identity beyond differences, there is no longer an incentive for the groups to be responsive to one another. After all, there is no need for me to leave my sphere if the other spheres are 'just the same'. In either case, the attempted synthesis generates indifference and separates more than it unites.

The relativist dilemma occurs when all participants demand equal validity for themselves and their context, and despite a formal unity, none of the groups requires the other to secure its own identity. When all sides possess their own identity in a relativistic sense, the need for exchange and mutual understanding disappears. Again, mutual indifference is the result. This time it is not 'indifference as sameness', but indifference between absolute others. I have nothing to learn from others, because relativism tells me that I am perfectly whole. Again, the result is an increased alienation that frustrates the desired unification.

In her recent article on Schiller's Aesthetic Letters, 'Der Mensch in seinem Wahn' in the journal Literaturen, Hanna Leitgeb warns us against what she reads as Schiller's totalitarian ideal of aesthetic education in the name of reason:

Die Vorstellung, die Natur des Menschen verändern zu müssen, um ihn vernünftig zu machen ist [. . . ein durch und durch fundamentalistischer Gedanke, der die Definitionshoheit darüber beansprucht, was vernünftig ist - und ein unendliches Totalisierungspotential in sich birgt, das sich politische wie religiöse Regime und Terroristen aller Couleurs zu eigen machen können. Schiller liefert mit seinem Text eine normative Grundlage, ja geradezu eine Handlungsanleitung für alle Utopisten, die meinen, einen neuen Menschen schaffen zu müssen. ${ }^{4}$

In addition, Leitgeb criticizes Schiller's strong dualistic oppositions. As is well known, Schiller's theoretical writings are charged with oppositions such as - to name but a few - nature/reason, life/law, matter/form and part/whole. In Leitgeb's eyes, Schiller's entire aesthetic-educational programme is geared towards the totalitarian overcoming of such antagonism:

Es ist die Crux dieser dualistischen Setzung, dass sie zu einem Ganzen, Reinen, Einen streben muss. In dieser Konstruktion steckt eine gehörige Portion Gewalt, [. . .] Und sie führt zu einer unglaublichen Beglückungshybris, die dem Künstler eine Propheten-, wenn nicht Gott-gleiche Funktion zuschreibt: Er befindet sich im Besitz der Wahrheit und ermächtigt den politischen Souverän, die Menschen zu erziehen. (Leitgeb, p.3)

\footnotetext{
${ }^{4}$ Hanna Leitgeb, 'Der Mensch in seinem Wahn', Literaturen, XII (2004), 2.
} 
On a superficial level, Schiller seems indeed to belong to that oft-deconstructed onto-theological philosophical tradition that privileges a rational foundation and permanent being over contradictory becoming. In the tenth letter, Schiller declares that he wishes to 'strive for a firm basis' (NA, XX, 34I). How can someone strive for a 'firm basis' without turning into a fundamentalist who excludes others and imposes his vision on them?

In Über Anmut und Würde, Schiller pays tribute to Kant's work, but he takes exception to Kant's 'strenge und grelle Entgegensetzung' (NA, XX, 284) and his 'Rigidität' (NA, XX, 285) when it comes to oppositions such as 'reason' and 'nature', 'person' and 'condition', 'duty' and 'inclination'. According to Schiller's reading, Kant has decided the conflict by an either/or logic. However, this is not how Schiller wants to deal with oppositions. An 'ideal' solution has to be one that does not annihilate, because such a procedure would lead to a solution that cannot last. The two ways are not alternatives from which we can choose either one or the other. Instead, it is necessary to integrate both sides, but without - and this is important - offering a naive third option. Schiller's oscillating approach strives to ensure both contact and separation. On the one hand, he blames Winckelmann for failing to consider the two as separate. ${ }^{6}$ On the other hand, contact between the two is constitutive of their mutual interaction: 'Beide Gesetzgebungen berühren hier [im Individuum] einander so nahe, dass ihre Grenzen zusammenfliessen' (NA, XX, 300-OI). Schiller avoids the either/or alternative because 'Der bloss niedergeworfene Feind kann wieder auferstehen, aber der versöhnte Feind ist wahrhaft überwunden' (NA, XX, 284; my emphasis). ${ }^{7}$ This is the essence of his critique of Kant.

Schiller himself prefers an adualistic logic, where both opposed poles remain separate and yet united. ${ }^{8}$ In the famous passage in Über Anmut und Würde, he therefore combines the logic of both/and with that of neither/nor:

Wenn nämlich weder die über die Sinnlichkeit herrschende Vernunft, noch die über die Vernunft herrschende Sinnlichkeit sich mit der Schönheit des Ausdrucks vertragen, so wird [... .] derjenige Zustand des Gemüts wo Vernunft und Sinnlichkeit — Pflicht und Neigung - zusammenstimmen, die Bedingung seyn, unter der die Schönheit des Spiels erfolgt [my emphasis]. (NA, XX, 282)

\footnotetext{
${ }^{5}$ Friedrich Schiller, On the Aesthetic Education of Man in a Series of Letters, edited by Elizabeth M. Wilkinson and L.A. Willoughby, Oxford, I967. Wilkinson/Willoughby translate the German verb 'streben' as 'struggle' rather than 'strive' (p. 7I).

6 'Aber was er vereinigt fand, nahm und gab er auch nur für Eines, und er blieb bei dem stehen, was der bloße Sinn ihn lehrte, ohne zu untersuchen, ob es nicht vielleicht noch zu scheiden sey' (NA, XX, 30I).

${ }^{7}$ All emphases are original unless otherwise noted.

${ }^{8}$ In Kant's Kritik der reinen Vernunft, the category of 'Gemeinschaft' refers to the 'Wechselwirkung zwischen dem Handelnden und Leidenden', and the corresponding form of judgement is 'disjunctive': 'Endlich enthält das disjunktive Urtheil ein Verhältniß zweier oder mehrerer Sätze gegen einander, aber nicht der Abfolge, sondern der logischen Entgegensetzung, sofern die Sphäre des einen die des andern ausschließt, aber doch zugleich der Gemeinschaft, in sofern sie zusammen die Sphäre der eigentlichen Erkenntniß ausfüllen, also ein Verhältniß der Theile der Sphäre eines Erkenntnisses, da die Sphäre eines jeden Theils ein Ergänzungsstück der Sphäre des andern zu dem ganzen Inbegriff der eingetheilten Erkenntniß ist; z.E. die Welt ist entweder durch einen blinden Zufall da, oder durch innre Nothwendigkeit, oder durch eine äußere Ursache. Jeder dieser Sätze nimmt einen Theil der Sphäre des möglichen Erkenntnisses über das Dasein einer Welt überhaupt ein, alle zusammen die ganze Sphäre. Das Erkenntniß aus einer dieser Sphären wegnehmen, heißt, sie in eine der übrigen setzen, und dagegen sie in eine Sphäre setzen, heißt, sie aus den übrigen wegnehmen. Es ist also in einem disjunktiven Urtheile eine gewisse Gemeinschaft der Erkenntnisse, die darin besteht, daß sie sich wechselseitig einander ausschließen, aber dadurch doch im Ganzen die wahre Erkenntniß bestimmen, indem sie zusammengenommen den ganzen Inhalt einer einzigen gegebenen Erkenntniß ausmachen' (\$ 9, A73/B99, my emphasis).
} 
In the Aesthetic Letters, Schiller follows the same logic. In Letters XIII and XIV, he argues against an either/or decision between being and becoming, and he makes it clear that the play drive enables us to experience the non-reductive, paradoxical relationship between the two. This is the configuration necessary for a lasting reconciliation, namely '[...] die Zeit in der Zeit aufzuheben, Werden mit absolutem Sein, Veränderung mit Identität zu vereinbaren. ${ }^{9}$ Instead of abolishing the opposition, he condenses it: 'neither is there time nor is time not', 'there is both becoming and being, both change and identity'. Purity and absolute equilibrium 'remain only an idea'; instead, we read in Letter XVI, '[. . . ] das Höchste wird in einer Schwankung [my emphasis] zwischen beiden Prinzipien bestehen' (NA, XX, 357). Consequently, in his idea of aesthetic freedom, Schiller confirms that the oscillating unity he describes leaves us in a 'problematic' state. Again in Letter XXIII he employs the disjunctive neither/nor logic:

[...] obgleich dieser Zustand [ästhetische Freiheit] an sich selbst weder für unsere Einsichten noch Gesinnungen etwas entscheidet, mithin unsern intellektuellen und moralischen Werth ganz und gar problematisch [my emphasis] läßt, so ist er doch die nothwendige Bedingung, unter welcher allein wir zu einer Einsicht und zu einer Gesinnung gelangen können. (NA, XX, 383)

In 'Zum Umgang mit Gegensätzen bzw. Gegensatzstrukturen', the Tübingen philosopher Friedrich Kümmel observes - and Leitgeb's interpretation suggests that he is right - that for 'the thinking human being, the attitude towards oppositional structures is in many important respects still new territory'. He surmises that human beings - following a biological matrix that is also noticeable in our linguistic oppositions - tend to think in alternatives that are designed in such a way as to exclude one another. ${ }^{10}$ Kümmel suggests that we emancipate our practice of thinking so as to progress beyond the either/or. The following definition can help us to appreciate Schiller's approach to oppositions:

Nicht-dualistische Lösungen müssten [...] wahrhaft integrativ sein und d.h. sie müssten sowohl die Dimension der Einheit bzw. des 'Ein Zusammen' anders ansetzen als auch die unverzichtbaren Trennungslinien an einer anderen Stelle markieren. Das 'Zusammen' verlangt ein den Widerspruch in sich aufnehmendes Sowohl-als-auch, die notwendige Abgrenzung, die Eröffnung eines von den respektiven Beschränkungen freien Feldes im Weder-noch. Wo weder das Ineinander noch das Getrenntsein von selbst gegeben ist, muß beides selbst erarbeitet werden. ${ }^{11}$

\footnotetext{
9 'Der sinnliche Trieb will, daß Veränderung sei, daß die Zeit einen Inhalt habe; der Formtrieb will, daß die Zeit aufgehoben, daß keine Veränderung sei. Derjenige Trieb also, in welchem beide verbunden wirken (es sei mir einstweilen, bis ich diese Benennung gerechtfertigt haben werde, vergönnt, ihn Spieltrieb zu nennen), der Spieltrieb also würde dahin gerichtet sein, die Zeit in der Zeit aufzuheben, Werden mit absolutem Sein, Veränderung mit Identität zu vereinbaren' (NA, XX, 353).

10 'Gegensatzstrukturen haben die menschliche Denk- und Wahrnehmungsweise und Schematisierung seiner Welt in Subjekt-Objekt-Struktur von vornherein bestimmt. Es liegt ihnen eine biologische Matrix zugrunde, die auch in sprachlichen Oppositionen ihren Niederschlag gefunden hat. Uns interessiert an dieser Stelle aber nur der sekundäre, logische bzw. paradoxlogische und dialektische Umgang mit ihnen, der vom Leben und von der Sprache nicht bereits vorprogrammiert ist', Friedrich Kümmel, 'Zum Umgang mit Gegensätzen bzw. Gegensatzstrukturen', (unpublished manuscript), currently available at http://www.friedrich-kuemmel.de.

${ }_{11}$ Kümmel, 'Zum Umgang mit Gegensätzen bzw. Gegensatzstrukturen', pp. 6-7.
} 
Contrary to Leitgeb's interpretation, in the aesthetic state nobody is 'in possession of the truth'. Rather, the aesthetic state breaks with our common practice of thinking in our 'natural', either/or logic of alternatives and therefore does not constitute a totalitarian overcoming. It allows the opposed Other to exist, without the false promise of a Hegelian dialectic of reconciliation within the concept. ${ }^{12}$

We can close with an example taken from Schiller's Wilhelm Tell. I read the Berta/ Rudenz relationship as a critique of the logic of unification that tacitly guides Rudenz's actions. Rudenz wishes to be together with the rich aristocrat Berta von Bruneck. In order to bridge the difference that separates him from her, he makes an either/or decision between his own sphere and Berta's sphere. Attinghausen warns him against joining Berta's sphere:

Die fremde falsche Welt ist nicht für dich,

Dort an dem stolzen Kaiserhof bleibst du

Dir ewig fremd mit deinem treuen Herzen! (NA, X, I68)

Das Ritterfräulein willst Du Dir erwerben

Mit deinem Abfall von dem Land - Betrüg Dich nicht! (NA, X, I7I)

Rudenz chooses between the two and leaves his life and his country behind.

During a hunting expedition, when the two are closer than they have ever been before, Rudenz decides to make the decisive step that will bring them together and reveals his love for her. Yet, despite the fact that Berta also confesses that she would like to love him, she insists that it is now impossible for her to be with him, because he stopped being who he was. ${ }^{13}$ Rudenz is clearly confused. Had he not done everything to ensure their unity? Had he not even sacrificed his own people? He replies: 'Von Euch, mein Fräulein, hör' ich diesen Vorwurf? / Wen such' ich denn, als Euch auf jener Seite!' (NA, X, I99). Berta makes it unmistakably clear that his journey towards her has failed. Despite the fact that he is now with her, he is precisely not with her: 'Mich denkt Ihr auf der Seite des Verrats / zu finden?' (NA, $X, 200$ ). Rudenz had started from a mistaken conception of unity. He had deemed it necessary to reduce the difference between them as much as possible. In this attempt, however, he also annihilated what Berta valued the most, himself. ${ }^{14}$ Berta now has to remind him:

Seid,

Wozu die herrliche Natur Euch machte!

Erfüllt den Platz, wohin sie Euch gestellt... (NA, X, 20I)

\footnotetext{
${ }^{12}$ In his study Harmonious Tensions, Steven D. Martinson also rejects reductive either/or polarizations. He argues that the real dynamics — between both the physiological and the idealistic aspects — within Schiller's work cannot be captured in terms such as 'dualism' and 'dialectical synthesis' (Harmonious Tensions: The Writings of Friedrich Schiller, Newark, I996, p. 213). See also Goethe's concepts of 'das tötende Allgemeine' and the 'Vereinigung der Entgegengesetzten' (MA, XII, 338) and the aphorism 'Allgemeine Begriffe und grosser Dünkel sind immer auf dem Wege entsetzliches Unglück anzurichten' (MA, XVII, 806).

${ }_{13}$ Dürft Ihr von Liebe reden und von Treue,

Der treulos wird an seinen nächsten Pflichten?

Rudenz tritt zurück

Der Sklave Österreichs, der sich dem Fremdling Verkauft, dem Unterdrücker seines Volks? (NA, X, I99).

${ }^{14}$ This is not to be mistaken for any essentialist conception of identity. Rudenz's identity was his relational 'position', the 'Platz' (NA, X, 2OI) that he abandoned in order to be with Berta.
} 
Their union can begin the very moment the quality of oscillation is restored and Rudenz realizes that what divides the two does not separate them.

Traditionally, we expect to find unity when all differences and contradictions have been resolved. Schiller's texts instruct us that what is required for 'a firm basis' might be the realization that, in order to be together, it is necessary to remain separate; in order to become one, it is necessary to remain different. Such a practice of thinking might enable us to conceive of new oscillating unions beyond relativism whether international or interpersonal - 'free $[\ldots]$ of the compulsion to infringe the freedom of others in order to assert [our] own' (Letter XXVII). ${ }^{15}$

\footnotetext{
${ }^{15}$ Friedrich Schiller, On the Aesthetic Education of Man in a Series of Letters, edited by Elizabeth M. Wilkinson and L.A. Willoughby, p. 2 I9.
} 